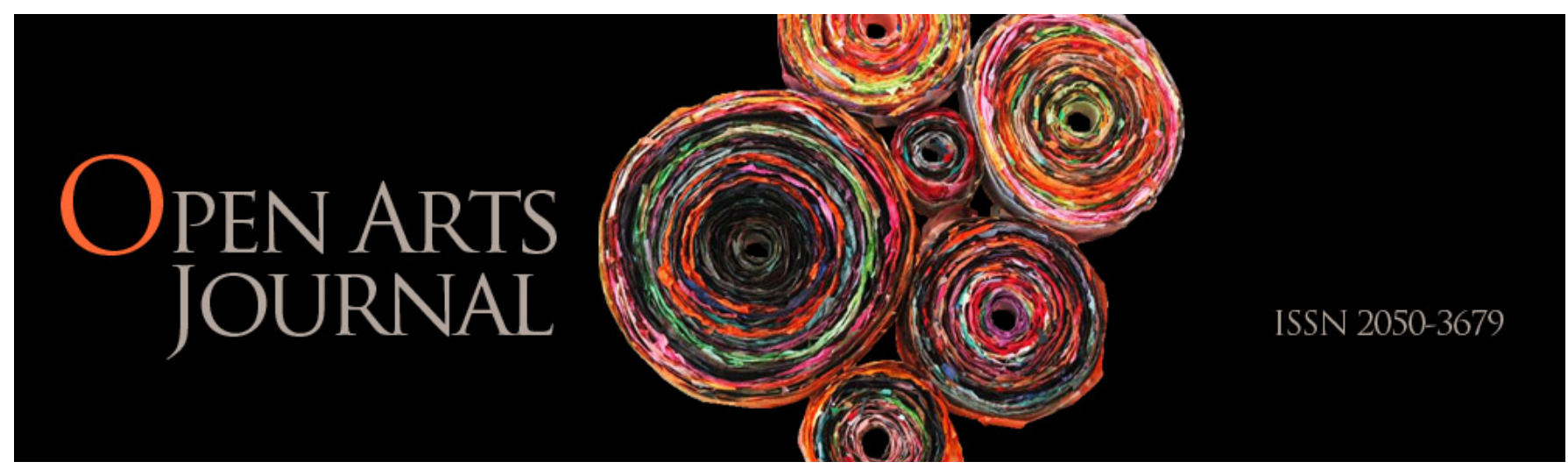

\title{
TRICK QUESTIONS: COSMOPOLITAN HOSPITALITY
}

\section{Eleanor Byrne}

This paper consists of two texts. The first explores the limits of cosmopolitanism in practice, taking as its subject the Life in the UK Citizenship Test, inaugurated under the Labour Government in 2005. It argues that the test exemplifies the predicament of all attempts at cosmopolitan hospitality as unconditional welcoming, through a discussion of the relation between questioning and welcoming the stranger. Establishing the relationship between cosmopolitanism and hospitality as envisaged in Derrida's reading of Kant it asks what kind of cosmopolitan hospitality is either possible or desirable by exploring what Derrida calls the 'perversions' inherent in the structures of hospitality. It focuses on the concept of the 'trick questions' that the state asks the foreigner observed by Derrida in his reading of The Apology of Socrates; questions that seem to invite answers but foreclose the possibilities of a free response. The second text asks how this logic that Derrida identifies can be pushed or coaxed into new ways of addressing the perceived threats of 'unconditional' hospitality through a reading of 'unconditional hospitality' as queer in the work of Tove Jansson

Eleanor Byrne, Manchester Metropolitan University

Ellie Byrne is Senior Lecturer in Contemporary Literature at Manchester Metropolitan University, UK. Her research and teaching covers twentieth century British and Postcolonial literature and theory. She has written on Salman Rushdie, intersections between postmodernism and postcolonial theory and postcolonial archives. Recent publications include a monograph, Homi K. Bhabha, (Palgrave, 2009), 'Texting Obama' Comparative American Studies, vol. I0, Double issue 2-3 (Co-Editor), 20I2. She is currently researching a monograph on the representation of Hawaii in contemporary literature and culture.

Trick questions: cosmopolitan hospitality

(Eleanor Byrne, Manchester Metropolitan University)

DOI: 10.5456/issn.5050-3679/20I3s08eb 
II Chua, L. (1998) Gold by the Inch, New York, Grove Press.

12 Dasgupta, R. (2006) Tokyo Cancelled, London, Harper Perennial.

13 Desai, K. (2006) The Inheritance of Loss, London, Hamish Hamilton.

I4 Dickinson, J. and Bailey, A.J. (2007) '(Re)membering diaspora: uneven geographies of Indian dual citizenship', Political Geography, vol.26, no.7, pp.757-74.

I5 Doty, R.L. (1996) 'Immigration and national identity: constructing the nation', Review of International Studies, vol.22, no.3, pp.235-55.

16 Fanon, F. (1967) The Wretched of the Earth, Harmondsworth, Penguin.

17 Gellner, E. (1983) Nations and Nationalism, Ithaca, Cornell University Press.

I8 Hemon, A. (2008) The Lazarus Project, London, Picador.

19 Hobsbawm, E. (1992) Nations and Nationalism Since I 780: Programme, Myth, Reality, Cambridge, Cambridge University Press.

20 Kant, I. (2010) 'Idea for a universal history with a cosmopolitan purpose', in G.W. Brown and D. Held (eds), The Cosmopolitanism Reader, Cambridge, Polity, Pp.I5-26.

2 I Marsh, N. (20I I) 'Desire and disease in the speculative economy: a critique of the language of crisis', Journal of Cultural Economy, vol.4, no.3, pp.30I-I4.

22 Medley, J. and Carrol, L.A. (2010) 'The hungry ghost: policy, capitalist transformation and laboring bodies in Southeast Asia', in L. Connell and N. Marsh (eds) Literature and Globalization:A Reader. London, Routledge, pp.282-97.

23 Mitchell, D. (1999) Ghostwritten:A Novel in Nine Parts, London, Sceptre.

24 Mitchell, D. (2004) Cloud Atlas, London, Sceptre.

25 Moretti, F. (2000) 'Conjectures on world literature', New Left Review, vol. I, pp.54-68.

26 Moretti, F. (2003) 'More conjectures', New Left Review, vol. 20, pp.73-8I.

27 Nussbaum, M.C. (2010) 'Patriotism and cosmopolitanism', in G.W. Brown and D. Held (eds), The Cosmopolitanism Reader, Cambridge, Polity, pp. I 55-62.

28 Palan, R. (2006) The Offshore World: Sovereign Markets, Virtual Places and Nomad Millionaires, Ithaca, Cornell University Press.
29 Shaxson, N. (201I) Treasure Islands:Tax Havens and the Men Who Stole the World, London, Bodley Head.

30 Sigmundsdóttir, A. (20II) 'Is Icelandic citizenship for sale?' The Guardian, 7 April, http://www.guardian. co.uk/commentisfree/20I I/apr/07/icelandic-citizenshipgolden-geese (accessed 8 April 20I I).

3I United Nations (1945) Charter of the United Nations and Statute of the International Court of Justice, together with Interim Arrangements concluded by the Governments represented at the United Nations Conference on International Organization, Berkeley, California University Press.

32 Wallerstein, I. (2004) World-Systems Analysis:An Introduction, Durham, NC, Duke University Press.

33 Xiaoping, D. (1987) 'More on "one country, two systems”, Beijing Review, vol.30, no. I4, pp.2I-2.

\section{TRICK QUESTIONS: COSMOPOLITAN HOSPITALITY}

\section{Eleanor Byrne}

\section{Abstract}

This paper consists of two texts. The first explores the limits of cosmopolitanism in practice, taking as its subject the Life in the UK Citizenship Test, inaugurated under the Labour Government in 2005. It argues that the test exemplifies the predicament of all attempts at cosmopolitan hospitality as unconditional welcoming, through a discussion of the relation between questioning and welcoming the stranger. Establishing the relationship between cosmopolitanism and hospitality as envisaged in Derrida's reading of Kant it asks what kind of cosmopolitan hospitality is either possible or desirable by exploring what Derrida calls the 'perversions' inherent in the structures of hospitality. It focuses on the concept of the 'trick questions' that the state asks the foreigner observed by Derrida in his reading of The Apology of Socrates; questions that seem to invite answers but foreclose the possibilities of a free response. The second text asks how this logic that Derrida identifies can be pushed or coaxed into new ways of addressing the perceived threats of 'unconditional' hospitality through a reading of 'unconditional hospitality' as queer in the work of Tove Jansson. 


\section{TEXT I}

\section{Unconditional Hospitality and Cosmopolitanism}

- The intercourse, more or less close, which has been everywhere steadily increasing between the nations of the earth, has now extended so enormously that a violation of right on one part of the world is felt all over it. Hence the idea of a cosmopolitan right is no fantastical, highflown notion of right, but a complement of the unwritten code of law - constitutional as well as international law - necessary for the public rights of mankind in general and thus for the realisation of perpetual peace.

(Kant, [1795] 1972, Perpetual Peace: A Philosophical Essay, p. I42).

\section{Q. 20. Is the statement below TRUE or FALSE?}

'The UN aims to prevent war and to promote international peace and security'.

\section{Life In The UK Citizenship Test, PRACTICE TEST}

12. Passing the Life in the UKTest, Official Practice Questions and Answers, (2009).

In Perpetual Peace, Kant's seminal account of the principle of a cosmopolitanism that can achieve world peace, he defines the Third Definitive Article of Perpetual Peace: 'the rights of men, as citizens of the world, shall be limited to the conditions of universal hospitality' (Kant, p. 137). This is not philanthropy, bestowed by a generous or loving host, but a right, 'a right of visitation', insisted upon because of man's 'common right of possession on the surface of the earth on which, as it is a globe we cannot be infinitely scattered, and must in the end reconcile ourselves to existence side by side' (pp. 137-8).

It is this 'right' of visitation that ensures the cosmopolitan project of perpetual peace, 'In this way far distant territories may enter into peaceful relations with one another. These relations may at last come under the public control of law and thus the human race may be brought nearer the realisation of a cosmopolitan constitution' (p.139, my emphasis). Hence, the right of visitation, the law of hospitality, leads to, or is a condition of, cosmopolitan interactions. Kant is clear about this specific form of 'right' as distinct from invasion or a takeover, citing the many contemporary colonial and imperial 'visitations' at theend of the eighteenth century that do not fall into the above definition.' However, as Derrida notes in On Cosmopolitanism (his address to the International Parliament of Writers in Strasbourg in 1999), Kant's model of cosmopolitanism does not embrace unconditional hospitality - rather, he places two limits on it. ${ }^{2}$ First, hospitality is not a right of residence, but a right of visitation; Kant limits the right of residence to that which is to be made dependent on treaties between states. Second, even though hospitality is a 'law', it depends on state sovereignty and as such it is controlled by the laws of the state and the state police (Derrida, 200I, p.22). For Derrida, Kant's project fails at this point because the principle of unconditional hospitality has already been discounted, and thinking unconditional hospitality, even if it cannot be enacted, must be part of any project for international peace.

Derrida's extensive discussions of hospitality as 'a contradictory conception, a thwarted conception or a contraception of waiting' (Derrida, 2000, p.00), have contributed to an important interrogation of the two contradictory impulses at work in the concept/ conception of hospitality. In 'Hostipitality' (2000) he notes that hospitality is an aporia. To offer hospitality is to 'extend an invitation', but 'radical hospitality consists in receiving without invitation' - thus even the existence of an invitation enables some limit to be placed on hospitality. Hospitality has to protect itself from itself, auto-immunize itself in some way. Hence, in Derrida's model, unconditional or pure hospitality is always impossible.

4 Hospitality gives and takes more than once in its own home. It gives, it offers, it holds out, but what it gives, offers, holds out, is the greeting which comprehends and makes or lets come into one's home, folding the foreign other into the internal law of the host which tends to begin by dictating the law of its language and its own

I 'But to this perfection compare the inhospitable actions of the civilized and especially of the commercial states of our part of the world. The injustice which they show to lands and peoples they visit (which is equivalent to conquering them) is carried by them to terrifying lengths. America, the lands inhabited by the Negro, the Spice Islands, the Cape, etc., were at the time of their discovery considered by these civilized intruders as lands without owners, for they counted the inhabitants as nothing. In East India (Hindustan), under the pretense of establishing economic undertakings, they brought in foreign soldiers and used them to oppress the natives, excited widespread wars among the various states, spread famine, rebellion, perfidy, and the whole litany of evils which afflict mankind', Kant ([1795] 1972) p.I39.

2 Derrida, On Cosmopolitanism and Forgiveness (London, 2001 ) is the text of the lecture he gave following an invitation to talk about their call for 'open cities' or 'cities of refuge' for asylum seekers, refugees and immigrants. 
acceptation of the sense of words, which is to say, its own concepts as well.

(Derrida, 2000, p.7)

So although hospitality is owed to the other if they are understood as a stranger, the category of stranger produces the notions of family, nation, state, and citizenship by which the other/stranger is measured and interpellated and made strange. This 'knowing nothing of' the stranger is accommodated by conditional hospitality through the necessity of questioning.

\section{The Foreigner Question:Taking the Citizenship Test}

4 The foreigner is, first of all, foreign to the legal language in which the duty of hospitality is formulated, the right to asylum, its limits, norms, policing, etc. He has to ask for hospitality in a language which by definition is not his own. This personage imposes on him translating into their own language and that's the first act of violence. 7

(Derrida,'Foreigner Question: Coming from Abroad/From the Foreigner' (Question d'etranger: venue de L'etranger), in Derrida and Dufourmantelle, 2000, p. I5).

4 Many foreign people wish to enjoy the freedoms that being a British citizen brings. They want to eat every day at a different Hungry Horse Inn and apply for their own Boots Advantage Card. But you cannot become a British Citizen unless you have extensive knowledge of our traditions. Therefore I have put together this quiz to see if you are ready yet. This is my improved version of the citizenship test, which I found to have many mistakes in it, such as incorrectly stating that Wales is part of the UK.

This test is multiple choice. Please mark your answers on your computer screen using an $\mathrm{HB}$ pencil. You have a certain amount of time of my choosing to take this test. If you make a mistake during the test or wish to ask any sort of question at all it will be held against you. 7

(emphasis added, 'Spoof Citizenship Quiz', Come Fly With Me, BBC Comedy Series)

In 'Foreigner Question', the first essay in Of Hospitality, Derrida recognizes that central to the notion of the foreigner is a kind of questioning, such that the foreigner 'is' a question.

- Before being a question to be dealt with, before designating a concept, a theme, a problem, a program, the question of the foreigner is a question of the foreigner, addressed to the foreigner [...] as though the foreigner were being-in-question, the very question of being-in-question, the question-being or being-in-question of the question. 7

(Derrida and Dufourmantelle, 2000, p.3)

If the foreigner 'is' a question, or produces questions, and puts the laws of the state into question, this is because he is what Derrida refers to as a 'foreignerson', one who challenges the law of the father, the host and the family from within, as a family member. Such an identity is intolerable, dangerous even, for the invited guest to whom hospitality is offered.

4 The Foreigner fears that he will be treated as mad (manikos). He is afraid of being taken for a son-foreigner-madman. "I am therefore fearful that what I have said may give you the opportunity of looking on me as someone deranged who is upside down all over, a crazy person who reverses everything from head to toe, from top to bottom, who puts all his feet on his head, inside out, who walks on his head."

(Derrida and Dufourmantelle, 2000, p.9)

The risks of being treated as mad, being seen as someone 'turned upside down' who will disrupt and threaten the laws of the state as they stand, threaten the guest even as hospitality is offered.The foreigner must be received, and as such must be questioned; once they have responded, they become subject to the law, having presented themself as subjects of the law. Hospitality consists then, not in welcoming, but in interrogating the new arrival. 'What is your name? Tell me your name, what should I call you, I who am calling on you, I who want to call you by your name? What am I going to call you? It is also what we sometimes tenderly ask children and those we love' (Derrida and Dufourmantelle, 2000, p.31).

The Life in the UK test is a computer-based test that constitutes one of the requirements for anyone seeking Indefinite Leave to Remain in the UK or naturalization as a British Citizen. It consists of 24 multiple-choice questions, lasts for 45 minutes, costs $£ 50$ to take, and is based on an official publication, Life in the United Kingdom:A Journey to Citizenship. There are no limits to the amount of times one may take it. If one passes it, with a pass mark of 18 or above correct answers one has fulfilled one aspect of the legal requirements for anyone seeking Indefinite Leave to Remain in the UK, or naturalization as a British Citizen. The Life in the UK test was first introduced by the Labour Government, 
under the steerage of then Home Secretary, David Blunkett. It became a requirement under the Nationality, Immigration and Asylum Act 2002. A pass in the test fulfills the requirements for 'sufficient knowledge of life in the United Kingdom', requirements that were introduced for naturalization in November 2005, and for settlement in April 2007. ${ }^{3}$

All questions involve ticking a box, and there are four types of question: multiple choice where four answers are offered and the correct one is to be ticked; a single statement which the candidate has to state is either true or false; two very similar statements which the candidate has to choose between and identify the correct one; and a second set of multiple choice questions where two of the four options need to be chosen as correct answers to the initial question. ${ }^{4}$

Its scope and mode of questioning, notwithstanding a will to hospitality on the part of the Labour government under which it was instituted, suggests a level of compliance with what Slavoj Zizek would identify as the systemic violence being produced in the act of questioning by the state. ${ }^{5}$ The 'foreigner' is constructed as such, not only because of being required to answer a set of questions, by ticking a box, not actually speaking in the other's language or writing in it, but demonstrating competence in reading the questions and interpreting the textbook in which the correct answers can be found. The textbook itself is the source of information for correctly selecting answers, rather than the knowledge one might have gained from a period of life that was lived in the UK. What are these questions if not the 'trick questions' that Derrida identifies as the prosopopeia of the law as it speaks to the 'foreigner'?

4 Far from himself interrogating or appealing to the law and rights of the city, he is himself questioned, apostrophized by the laws. They address themselves to him to ask him questions, but false questions, simulated questions, rhetorical questions. Trick questions. All he can reply is what the Laws, in their prosopopeia wish and expect him to reply. It is the famous

3 See Mark Oliver (2002) 'Citizenship Tests for Immigrants', The Guardian, 7 February,

http://www.guardian.co.uk/uk/2002/feb/07/immigration. immigrationandpublicservices.

Details of the current test can be found online at http://www.ukcitizenshiptest.co.uk/.

4 Passing the Life in the UK Test, Official Practice Questions and Answers (2009).

5 'There is what I call 'systemic' violence, or the often catastrophic consequences of the smooth functioning of our economic and political systems', Slavoj Zizek (2008) p.I. prosopopeia of the Laws in the Crito, which you should read closely for yourselves. 7

(emphasis added; Derrida and Dufourmantelle, 2000, p.3I)

\section{Trick Questions:}

Is the following statement TRUE or FALSE?

"The UK football team is very important to British People"

(Practice Test 10, Passing the Life in the UKTest: Official Practice Questions and Answers, 2009).

Q 16. Is the statement below TRUE or FALSE?

"It is legal to carry a small amount of cannabis"

(Practice Test I I, Passing the Life in the UK Test: Official Practice Questions and Answers, 2009).

\section{Q. 22 Is the statement below TRUE or FALSE?}

"It is common for employers to ask women to leave their jobs when they marry"

(Practice Test 5, Passing the Life in the UK Test: Official Practice Questions and Answers, 2009).

Where does Father Christmas come from? Lapland Iceland

The North Pole

('Mock Citizenship Test', based on the content of Life in the UK, BBC News, 16 June 2005)

\section{Q 17.Which of these statements is correct?}

A:The women who campaigned for more rights for women were called Suffragettes.

$\mathrm{B}$ :The women who campaigned for more rights for women were called Huguenots.

(Practice Test 12, Life in the United Kingdom: Official Practice Questions and Answers, 2009).

The Public House is an important part of British life. What temperature does it have to be before it is acceptable for a man to take his top off while having a pint outside a pub?

(Come Fly With Me, BBC Comedy Series, Spoof Citizenship Quiz)

QI0. Is the following statement TRUE or FALSE?

'The Government can control what is written in newspapers in the UK'

(Practice Test 13, Passing the Life in the UK Test: Official Practice Questions and Answers, 2009, p. 105) 


\section{Result:}

You have learnt a small amount about our country and it is possible that other foreign people will be fooled but not us. Your foreignness looms to us larger than Big Ben through the morning mist. I suggest you return to your country and call yourself 'Lord Chimneysweep' as this is the nearest to being British you will ever get.

\section{('Spoof Citizenship Quiz', Come Fly With Me, BBC Comedy Series)}

The Life in the UK Test might initially appear to be the last place that one may look for an example of either cosmopolitanism or hospitality. Indeed, beyond the absurdities of juxtapositions of real and satirical test questions lie other concerns about the content of the official Life in the UK book beyond the scope of this discussion, but which have been addressed elsewhere. ${ }^{6}$ Certainly, as an intervention into immigration debates and cynical, media-fanned hysteria about 'foreignness' in Britain, the test appears to be conceived to 'answer' a rightwing political agenda focusing on the perceived 'assault' on supposed traditions and customs that have dominated public representations of migrants in the second half of the twentieth century. The test accommodates this narrative by acceding to the idea that one must 'know' something in order to be British, but it also uses a dissident cosmopolitan sleight of hand to insist that the knowledge required is not of a subjective account of essentialist national identity, but that of one's own rights under British law.

Perhaps the most interesting aspect of the makeup of the test is in the content and scope of the questions asked, which focus substantially on the law, such as the rules surrounding the use of a television license in a House in Multiple Occupation (HMO), the legal age for child labour, how to register a birth and open a bank account, how to apply for work, obtain a National Insurance number, or claim Job Seeker's Allowance. Life

6 As Mehdi Hassan notes (New Statesman, 4 July 20I2), the textbook itself performs an act of rewriting history: 'It is also worth bearing in mind that the questions posed in the current citizenship test are based on the Home Office pamphlet Life in the United Kingdom:A Journey to Citizenship. This is a deeply disturbing document that rewrites British colonial history and presents a skewed and reactionary view of the past. Consider the following passage: "For many indigenous peoples in Africa, the Indian subcontinent, and elsewhere, the British Empire often brought more regular, acceptable and impartial systems of law and order than many had experienced under their own rulers, or under alien rulers other than Europeans ... Public health, peace and access to education can mean more to ordinary people than precisely who are their rulers"'. in the UK includes a 25-page 11,000 word introduction to British history written by Professor of Political Theory, Sir Bernard Crick. Crick, a socialist, had previously been adviser to Labour Party leader Neil Kinnock in the 1980s and was invited to chair the citizenship committee by his former student David Blunkett.' Crick was also the author of the 1998 report on teaching citizenship in schools that resulted in the introduction of Citizenship as a part of the English National Curriculum in 2002.

Life in the UK appears to have been written as a guide to one's rights in the UK, one that figures the law as something that will protect prospective citizens from exploitation, or clarify areas of the law that prevent infringements of human rights. As such it is a sheep in wolf's clothing, a text working hard to avoid prescriptions about Britishness, and to offer practical information for those settling in the UK. A BBC news report on Crick's appointment offers the following appraisal of the rationale for the test.

Professor Crick has played down suggestions that the test was a hurdle designed to weed out applicants for citizenship. He said it would focus more on practical issues about living in the UK. "At the moment when immigrants come in they don't receive ... any information on life in Britain. For example, simple things like hospitals are free, the police don't beat you up if you go to them for help, you don't go to hospital without going to your GP first". Such things could "cause a great deal of confusion, problems for the immigrant and, of course, for some people in the host communities," he added. He said the "main thrust" of his committee's work would be to create a syllabus for English language teachers that weaves in "some of this content". ${ }^{8}$

This aim is reflected in the type of questions below:

Q I3. If you are homeless or have problems with your landlord, you can get help at which TWO of the following places?

Shelter

The Citizen's Advice Bureau

The Government

The Police

(Passing the Life in the UK Test:Official Practice Questions and Answers, Practice Test 12)

7 See http://news.bbc.co.uk/I/hi/uk_politics/2248319.stm (10 September 2002).

8 See http://news.bbc.co.uk/I/hi/uk_politics/22483/9.stm (10 September 2002). 
Q 6. Is the statement below TRUE or FALSE?

'Your employer can dismiss you for being a Trade Union member'.

\section{(Passing the Life in the UK Test: Official Practice} Questions and Answers, Practice Test 9)

At the time of the launching of this test various media paid critical attention to it. The BBC News website producing a mock test based on the information contained in the official government publication. Channel 4 subsequently used the official test to open their version of a multicultural documentary, under the provocatively titled series, Make Bradford British, that brought a multicultural range of British citizens into a Big Brother-style house to discuss their views about identity and nation. Channel 4 provides a version of the test on the web pages associated with this programme. ${ }^{9} \mathrm{~A}$ spoof test is also available on the website of the comedy series Come Fly With Me. ${ }^{10}$ The test's attractiveness to the satirist not only reflects the dynamic and conflicted ways in which Britishness might be understood to exist or not, both in its relation to other internal national differences, and in relation to the multiplicities of behaviours that might be seen to represent this elusive identity. There is always already something ridiculous about the test: as the Bradford programme makes clear, it is perfectly possible to fail the test and already be British. Knowledge of, say, the percentage of the British population that live in Scotland has never been a defining criteria for qualifying to be British, even for the population of Scotland. The test cannot test the thing it claims to.

The striking difference between most of the mock versions of the test and the official test is that the official test almost meticulously avoids the question of culture as far as it is able, with some minor references to customs and Royalty, and finds itself turning to questions of law, rights, responsibilities, with a very light sprinkling of history, which largely focuses on the history of migrancy to the UK and the gaining of voting rights. One might expect this from a document authored by a Left leaning government, and indeed it might arguably be well paired with Danny Boyle's Opening Ceremony for the Olympics in London 2012. Like Boyle's ceremony, which celebrated Britishness whilst invoking a radical political tradition, Crick's text offers a radical history of Britain from below, a text which privileges subaltern perspectives and insists on

9 See, Make Bradford British (first aired I March 20I2), http://www.channel4.com/programmes/make-bradfordbritish/articles/whos-who.

10 See http://www.bbc.co.uk/comedy/comeflywithme/ citizenship/quiz.shtml. the good citizen being one who is well informed of their rights and protected from exploitation.

Notwithstanding the laudable aims of the text and test, to embed crucial information that would offer support to a migrant in Britain, the test remains bound up by its function of questioning the foreigner. In doing so it cannot avoid the paradoxical logic of hospitality. The first edition also included an introduction by Bernard Crick welcoming immigrants to the UK, expressing the hope that they apply for citizenship, and stating the country's need for both skilled and unskilled migrants. In the second edition, this introduction was removed. Nor are candidates tested on the first chapter, which covers British history. It is this lack that has more recently been attacked by Conservative Home Secretary Theresa May, who announced plans to redraft the Labour Party authored test in favour of an emphasis on 'knowledge of traditional British culture and history', what she terms a 'patriotic guide'". May's revisions of the test finally undo what I would argue is its cosmopolitan gesture of offering citizenship through an emphasis on rights, rather than knowing an always politically directed 'British' syllabus.

\section{TEXT I I}

\section{Pure Hospitality:A Queer Moment?}

There is no hospitable house. There is no house without doors and windows. But as soon as there are doors and windows it means someone has the key to them and consequently controls the conditions of hospitality. There must be a threshold.

\section{(Derrida, 2000, ‘Hostipitality’, pp.70-7I)}

A curious system of thought, or of language, or of social organization (in fact all of them at once) is implicit in the word parasite. There is no parasite without a host. The host and the somewhat sinister or subversive parasite are fellow guests beside the food, sharing it. On the other hand, the host is himself the food, his substance consumed without recompense, as when one says, 'He is eating me out of house and home'.

(Miller, 1977, p.439)

II For a full discussion of this issue, see Thom Brooks (2013) The 'Life in the United Kingdom' Citizenship Test: Is It Unfit for Purpose? Durham, Durham University, http://thombrooks. info/Brooks_citizenship_test_report.pdf.

For a report on Theresa May's introduction of the revised test see also http://www.guardian.co.uk/uk/20 I 2/jul/0 I/ukmigrants-patriotic-citizenship-test (I July 20I2). 
(But what of the house with the key under the mat, with the door on the latch?)

My beloved parasites, those two lives that ate me out of house and home, ate my food both at the same time and before me, at my invitation without being invited, demand the story again. 'Read the one where Stinky eats Moomin's house'.

In Tove Jansson's Moomin comic strip, one story, Moomin and the Brigands, stands out in relation to the problematics of unconditional hospitality. It opens with the child/animal hero Moomintroll in the middle of a crisis where he is trying to maintain his position as host to an extensive range of guests who have already (always?) taken over his home. Moomin and the Brigands opens with Moomin's house overrun by 'friends and relations', conversing with his friend Sniff and struggling to tell his houseguests that he wants them to leave.

Moomin: Oh, Sniff! I have I5 guests and relations in my house! It has given me an awful headache!

Moomin: It's so difficult to tell your guests that you like to be in your own bed sometimes ...

Sniff:Turn them out you idiot!

Moomin: But that would be ill-mannered! It's so much easier and nicer to say yes!

Sniff: Be a Man, Moomin! Go and tell them to leave at once.

Moomin's ambiguous situation as a child/creature who lives alone in his large house militates against the possibility of his being a 'man' and asserting the rights of the host. One might suggest that he illustrates the predicament of the unconditional host, who attempts to meet every request from his guests, but asks nothing in return, and who cannot control who enters his home. Moomin arrives home from his visit to complain to Sniff only to find a mass of 'poor relations' at the door. He tells them he already has house-guests and they will have to sleep in the drawers. Nonetheless, the 'poor relations' stream in through the open front door.

\section{'Poor Relations: No Cocktails?}

Moomin: Excuse me l'll sell the mat and buy some ....'

The poor relations refuse to sleep in the drawers and Moomin builds them all beds. Moomin then goes outside to sleep in a hammock strung up in a tree. The next day Sniff persuades Moomin to put a hosepipe down the chimney to flood them out, but the guests float around playing on their beds having fun. Sniff then enters the house as a 'guest' wearing a large sign saying 'Danger Mumps!' But all the guests claim they have already had mumps. Sniff then persuades Moomin to go down into the cellar and make noises to scare the guests. They come bursting into the cellar brandishing weapons, attacking Moomin, until he has to shout 'DON'T! I'm Moomin. Don't murder your poor host'.

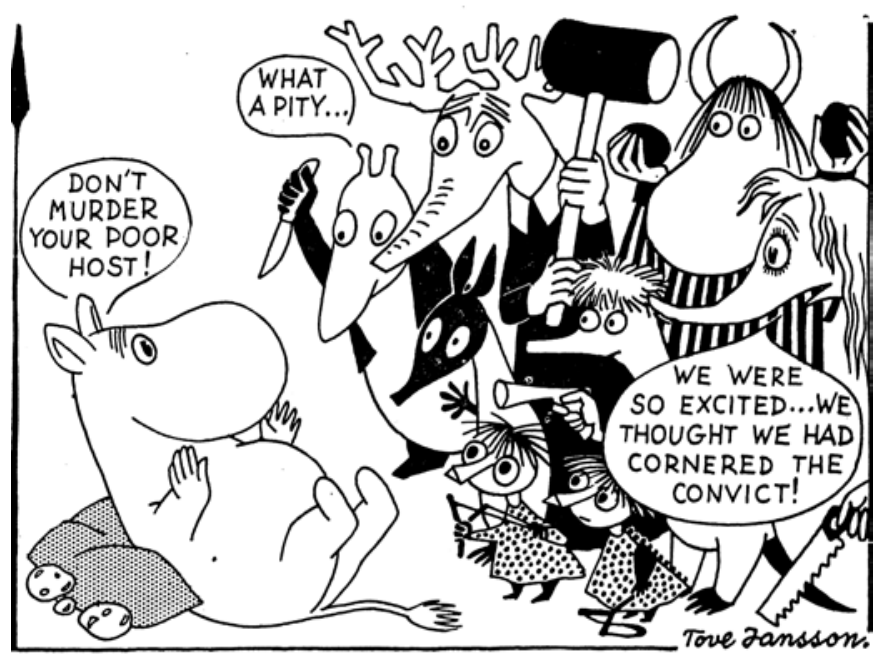

Figure I. Don't murder your poor host!

Reproduced by kind permission of Bull's Press, Stockholm.

In despair Moomin and Sniff go to search out Stinky, a creature that no one can stand, who they invite to come and stay to 'stink out' the guests. This has the desired effect and all the guests leave in a hurry. Moomin climbs into his own bed with Stinky lodged upstairs but Moomin is awoken by noises and parts of the ceiling falling in. Stinky has started eating the house. Stinky requests salt to accompany the chairs he is eating and Moomin complies. Moomin offers cheese, pancakes and ice-cream as a substitute, but Stinky insists the only thing that tastes good is the house itself.

Moomin: Isn't there ANYTHING else you would like to eat?

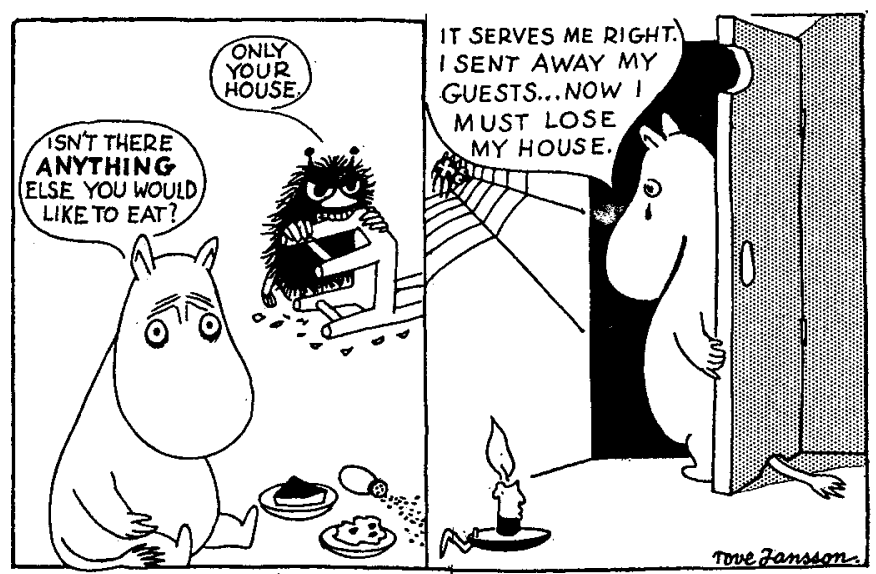

Figure 2. Stinky starts eating the house.

Reproduced by kind permission of Bull's Press, Stockholm. 
Stinky: Only your house

Moomin: It serves me right. I sent away my guests... now I must lose my house.

Moomin understands his fate to be a suitable punishment for his failure to provide 'pure' hospitality. Unhomed and shamed, Moomin then has to begin his adventures as his house has been entirely eaten: he is, in a phrase emphasized by J.H. Miller, eaten 'out of house and home' (Miller, 1977, p.439).

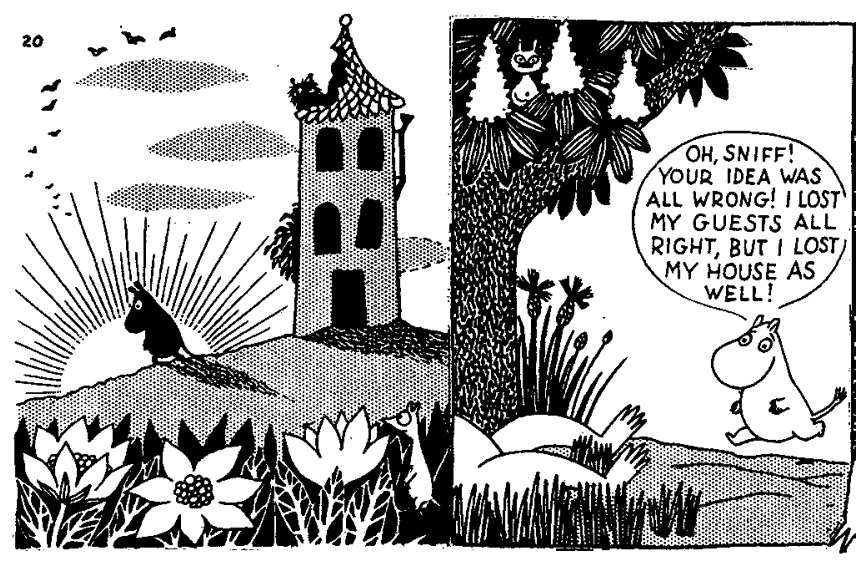

Figure 3. Moomin has to leave home as Stinky eats the house. Reproduced by kind permission of Bull's Press, Stockholm.

Up to this point Jansson's story could be said to adhere to Derrida's model of the aporia of unconditional hospitality, where imposing no limits on the hospitality you offer, not policing the borders or the threshold of your house and not imposing any conditions on the behaviour of the guests opens up the danger of being overrun, or murdered.

If I am unconditionally hospitable ... I must be unprepared, or prepared to be unprepared, for the unexpected arrival of ANY other. Is this possible? I don't know. If however, there is pure hospitality ... it should consist in this opening without horizon, without horizon of expectations, an opening to the newcomer whoever that may be. It may be terrible because the newcomer may be a good person or may be the devil; but if you exclude the possibility that the newcomer is coming to destroy your house ... there is no hospitality ... For unconditional hospitality to take place you have to accept the risk of the other coming and destroying the place, initiating a revolution, stealing everything or killing everyone.

(Derrida, 2000, p.3I)

In Derrida's examples, the unconditional form of hospitality risks certain things, 'revolution, stealing, and killing' (p.3I). This implies a model of 'safe' conditional hospitality that is opposed to the risky unconditional one; unconditional hospitality can only be considered dangerous if conditional hospitality is somehow safe. Derrida's deconstructive gesture is to identify a binary opposition and reverse it in order to reveal the violent hierarchy it contains. The deconstructive moment demonstrates the ways the opposition contradicts itself, or the way an assertion undermines itself.

Yet while Jansson's story demonstrates the humour of Moomintroll's 'pure' hospitality being impossibly foolish and self-defeating, self-annihilating even, it is also this 'queer' act on Moomin's part that produces all his subsequent narratives, adventures and his arrival at an identity based on reciprocity and love in the closing section of the story. Moomin's wide eyes, ungendered body, hippopotamus-like face and distended stomach suggest he is pregnant with the possibility of becoming himself. His enacting the unconditionality of hospitality, one that asks no questions of the 'poor relations', is arguably close to Derrida's description of unconditional hospitality as endangering everything, as the house itself is destroyed. But for Moomin it could be viewed as a 'necessary disaster' that inaugurates his narrative. Furthermore, if Moomin might be fruitfully read as an emerging queer subject, then the 'disaster' of his own beginning, from a hetero-normative point of view, would be the more productive disaster of being himself as a queer subject. ${ }^{12}$

As Peggy Kamuf notes, the value of understanding the impossibility of pure hospitality at a conceptual level is the ways in which this enables thinking about the kinds of hosting which take place every day, i.e. welcoming a guest into your house. It enables interrogation of the political limits placed on hospitality as it is practised by states, organisations or institutions. 'To think the unconditionality of such concepts is not at all to remove thought from the practical experiences we wish to call hospitality, gift, foreignness or justice' (Kamuf, 2006, p.207). The fact that unconditional hospitality is 'impossible' in practice does not prevent us from entertaining our guests in the name of hospitality, but for Derrida a pure hospitality has never 'happened'.

The paradox of hospitality is that it is only offerable by asserting your own rights to hospitality, as head of the house and with control over the laws and limits to the ways in which the guest must behave. However, a queer reading of Jansson's story might suggest an intervention could be made in this deconstructive

I2 For a critical account of the relationship between failure and queer subjectivity see Judith Halberstam (20I I), which theorises alternatives to conventional understandings of success in a heteronormative capitalist society. 
model. Moomin is not able to claim the status of the host, as there is no head of the house, so hospitality becomes unconditional, even though Moomin lives in the house. Only when threatened physically by his guests does he claim to control the goings on in the house: 'Don't kill me! I'm your "host". To an extent Moomin's model of 'hosting', as a failed host who cannot contain his guests in any way, appears to conform to Derrida's warnings. No-one intervenes to clear his house: there is no master of the house, there is no family, no circle of friends yet, except his confidante, Sniff. There is no authority figure, and although Sniff tells Moomin to 'be a man', Moomin is not one and is without his parents or any kind of paternal authorisation. He offers unconditional hospitality, a queer unauthorized hospitality, which is what Derrida would call the 'Law' of hospitality rather than the one based on any laws that might govern how hospitality is actually offered that depend upon state and city laws.

As Moomin is not a 'man', but I would argue a queer child/animal, he simply will not be able to host. In his critical accounts of conditional hospitality Derrida clearly demonstrates that hospitality is both given and received, authorized and authored, exclusively by men. He suggests that 'It's the familial despot, the father, the spouse, and the boss, the master of the house who lays down the laws of hospitality.' (Derrida, 2000, p. I49), leading Penelope Deutscher to explore Derrida's interest in women's traditional role as facilitating relations between men (2005).

Indeed, it is most specifically in his writing on hospitality that Derrida considers the historical role of women in traditional exchanges, transactions and social bonds between men, when: 'in the name of hospitality all the men are sent a woman' (Derrida, 2000, p. 155). The contexts discussed in Of Hospitality, in which women are the means through which hospitality is exchanged between men, include biblical stories in which the woman is figured as the wife who brings food, or the daughter or concubine provided sexually to save the guest - as in the tale of Lot's daughters, and again in the tale of the pilgrim on Mount Ephraim in Judges (Pp.I5I, I53).

In the name of hospitality the host must protect his guest at all costs when that guest is threatened from outside the house, even at the expense of protecting his own family members. In the case of the tale of Lot's daughters, the meaning of this hospitality is closely aligned to the affirmation that hospitality between men is homosocial, not homosexual - that is to say, the men who demand access to the guest in the text Derrida discusses are the Sodomites, seeking to 'penetrate' or 'outrage' the man inside the house who is a guest. Lot, the male host, refuses this request at the expense of the women inside the home, by offering his daughters to the men. They are then 'used' by the male crowd outside as a substitute for their original request for the male guest. A dominant reading of this tale is that it attempts to illustrate the aporia of hospitality, the host who goes to any lengths to look after his guest finds he has sacrificed his daughters; the host has become hostage. But he does not offer himself, so although he might be figured as 'hostage', he manages to retain some purchase on hosting through the sacrifice of female guests or family members. The particularity of the threat to the guest from sodomy, might shift our reading from perceiving this as a 'cautionary tale' about the limits of hospitality that relate to not being able to protect one's daughters, to one in which the daughters are expended in order to preserve the homosocial relations that underpin hospitality.

This scenario rehearses the threat to the authority of the host that is caused by the host's own desire for the guest. It threatens the host's reputation, as one who allows the guest to stay, who invites and beseeches the guest to stay. The host protects this reputation in the tales that Derrida cites, by showing that the relation between himself and his host is not homosexual and that such a possibility is excluded, since a condition of 'conditional' hospitality is that it must preserve heterosexual relations. Nothing is clearer in the two accounts that Derrida offers. Hospitality must stand against homosexual desire. It must be understood to preserve that limit at all costs, such as through the rape and violation of women in preference to a sexual encounter between men. The man who takes another into his house as a guest must demonstrate he is not seeking or open to a sexual relation with him, nor will he expose him to a relation with other men. As Mark Westmoreland argues "It would be assumed that the host secures the house in order to "keep the outside out"' (Westmoreland, 2008, p.6). In the two stories offered by Derrida, the men are outside the house demanding the guest be brought out to them, but one might read this as a kind of figural externalizing of the potential for sexual relations to take place inside the house.

In Jansson's text this tension between hospitality as underpinning heterosexual relations or introducing the perverse/queer is perhaps held in the fabric of the house itself. As the house is dismantled by Stinky, the roof and walls, the doorway and threshold disappear, the house it 'turned inside out', as bit by bit the guest eats it, so that he 'hosts' it inside himself. One of the things that unconditional hospitality seems to do is to 
threaten to undo the law, in this case (and all cases) the law of the father.The appeal of unconditional hospitality to the emerging queer subject is the route it offers that subjectivity away from the very real physical dangers of guaranteeing homosocial hosting.

As a queer account of subject formation, does Janssen's story tell us what Derrida gestures towards, that hospitality in its conditional form is only available to men in a hetero-normative framework - that the roles of host and guest both, have gendered positions that are barely visible, but ones that are critically important to this model? For Jansson, Stinky's appetite and Moomin's facilitation of it inaugurates her storytelling. It is Moomintroll's first adventure. His house is eaten by his guest, and it is this staging of the ingesting that produces the queer aesthetic of the Moomins.

\section{Bibliography}

I Come Fly With Me, BBC Comedy Series, http://www. bbc.co.uk/comedy/comeflywithme/citizenship/quiz. shtml.

2 Derrida, J. (200I) On Cosmopolitanism and Forgiveness, London and New York, Routledge.

3 Derrida, J. (2000) 'Hostipitality', Angelaki: Journal of Theoretical Humanities, vol.5, iss.3, pp.3-18.

4 Derrida, J. with Dufourmantelle, A. (2000) Of Hospitality, Stanford, Stanford University Press.
5 Deutscher, P. (2005) 'Derrida's impossible genealogies', Theory and Event, vol.8, no. I, n.p.

6 Halberstam, J. (20I I) The Queer Art of Failure, Durham, NC, Duke University Press.

7 Jansson, T. (2006) 'Moomin and the brigands', in Moomin:The Complete Tove Jansson Comic Strip Volume I, Montreal, Drawn and Quarterly.

8 Kamuf, P. (2006) 'From now on', Epoche, vol. I0, no.2, Pp.203-20.

9 Kant, I. ([1795] 1972) Perpetual Peace:A Philosophical Essay (trans. M. Campbell Smith), New York and London, Garland.

10 Life in the United Kingdom, Official Practice Questions and Answers (2009), London, TSO.

II Miller, H.J. ( 1977) 'The critic as host', Critical Inquiry, vol.3, no.3, pp.439-47.

12 'Mock Citizenship Test', BBC News, 16 June 2005, http://news.bbc.co.uk/I/hi/magazine/4099770.stm.

13 Westmoreland, M.W. (2008) 'Interruptions: Derrida and hospitality', Kritike, vol.2, no.I, Pp. I-I0.

14 Zizek, S. (2008) 'Introduction:The tyrant's bloody robe', in Violence: Six Sideways Reflections, London, Profile Books, pp. I-7. 